Middle East Journal of Agriculture Research

EISSN: 2706-7955 ISSN: 2077-4605

DOI: 10.36632/mejar/2020.9.1.3
Volume : 09 | Issue : 01| Jan.-Mar. | 2020

Pages:34-45

\title{
An analytical study of wheat storage allocation in Egypt between current situation and desired outcomes
}

\author{
Asmaa Mohamed El-Tokhy Bahloul ${ }^{1}$ and Mohamed Osman Abdel Fatah ${ }^{2}$ \\ ${ }^{1}$ Department of Agric. Economics, Faculty of Agriculture, Benha University, Egypt. \\ ${ }^{2}$ Department of Agric. Economics, Faculty of Agriculture, Ain Shams University, Egypt.
}

Received: 30 Oct. 2019 / Accepted 25 Dec. 2019 / Publication date: 15 Jan. 2020

\begin{abstract}
The strategic stock of domestic and imported wheat economically and in terms of security are considered as the most important factors that Egyptian food security underpin on it, The strategic stock of wheat in Egypt is estimated to be sufficient for consumption of wheat in Egypt within the next three months, with the aim of avoiding global fluctuations in prices and quantities, which required that the state directs all its efforts to develop storage methods to preserve the wheat crop in quantitative and descriptive terms. The research problem was represented in the low level of technology and storage equipment leading to an increase in the percentage of agricultural losses, especially in the storage stage, in addition to the shortage in developing and providing storage capacities in proportion to the quantities required to be stored to meet the increasing consumer demands. Where the research relied on the use of the transportation model in wheat storage in the governorates of Egypt now and in the future.

By studying the regression relationship with the double logarithmic form between the quantity of wheat supply as an independent variable (X) and the amount of agricultural losses as a dependent variable $(\mathrm{Y})$ it was found that there is a direct relationship between the quantity of supply and the amount of losses, where the value of the correlation coefficient between them was 0.97 between the two variables, where it was found that an increase in the quantity of wheat supplied by $1 \%$ leads to an increase in wheat loss by around $1.8 \%$.

The research also made many attempts that amounted about (35) attempts to reach the best transportation pattern for wheat in Egypt at the minimum transportation costs, where the results showed that the most important storage capacities proposed to be established in those governorates and referred to as dummy variables distributed over the governorates under study (except Cairo and Qalyobia) .

The total transportation cost of wheat that distributed over the storage capacities in the various governorates amounted to 150.96 million pounds for the year 2018. While the total estimated cost of transporting 15.5 million tons and distributing it to the storage capacities proposed to be established is minimized to around 149.37 million pounds, as it is less than the actual model about 1.59 million pounds.

The total estimated cost of transporting 18.5 million tons and distributing it over the storage capacities proposed to be established is minimized to around 147.77 million pounds, to be less than the actual model by about 3.19 million pounds.
\end{abstract}

Keywords: Silos, Lost, Storage, Allocation, Transportation Model.

\section{Introduction}

The wheat crop is considered one of the main cereals crop and the most important strategic crops which interest to economic policy makers, where local production is not suffice the population needs, which leads to import to fill the deficit, and increase the burden of the import bill, especially in status of the liberalization of the exchange rate and the continuous rising in prices globally.

However, wheat production and storage has become one of the most important issues facing Egypt at the present and in the future due to the limited number of countries that can export wheat, then they are subject to the rules of oligopoly markets where a limited number controls the setting of prices, distribution of shares, and the conditions of production and storage subject to natural and climatic changes, in addition to the countries that export wheat, use the food weapon as one of the pressing factors in their policies in the strategic field on the importing countries. 
The wheat crop is characterized by the seasonality of harvest and the consumption is continuous during the year, where the Egyptian food behavior depends on wheat as the main food which described as the main source of the bread industry, the strategic stock of domestic and imported wheat economically and in terms of security is considered one of the most important factors that Egyptian food security underpin on it .

The strategic inventory of wheat in Egypt is estimated to be sufficient for consumption of wheat in Egypt within the next three months, with the aim of avoiding global fluctuations in prices and quantities, which required that the state directs all its efforts to develop storage methods to preserve the wheat crop in quantitative and descriptive terms.

\section{The problem and goal of the study:}

The Arab region generally, and Egypt specially, witness a lot of economic fluctuations and political troubles, in addition to that, the increasing of population growth rates in Egypt, Moreover, The low level of technology and storage equipment leads to an increase in the percentage of agricultural losses, especially in the storage stage, in addition to that, the shortage in developing and providing storage capacities in proportion to the quantities required to be stored to meet the increasing consumer demands. which pay attention to the need to achieve economic stability and raise the food security factor for the wheat crop in the long run through a reconsideration of planning or the wheat storage allocation in Egypt to achieve the desired maximum storage capacity

\section{Research method and data sources:}

The research relied on the use of a descriptive and quantitative analysis method, such as percentages, averages, some economic indicators, simple regression and general trend equations, in addition to that, using the transportation model to plan wheat storage in the governorates of Egypt. The research also relied on the secondary data contained in agricultural economy bulletins for the Economic Affairs Sector of the Ministry of Agriculture, food balance bulletins, the Food and Agriculture Organization, the Egyptian Holding Company for Silos and Storage, as well as studies and researches related to the subject of the research, and the opinions of some experts in wheat storage.

\section{Results and Discussion}

\section{Development of food security for wheat and its products:}

\section{A- Development of the quantity of wheat production:}

Table (1) and Figure (1) show the evolution of the quantity of wheat production during the period (2000-2017), it was found that the quantity of wheat production reached a minimum in 2001 about 6.26 million tons, while it reached a maximum during 2015, when it was estimated at 9.61 million tons with an average about 7.99 million tons during the study period.

By studying the general time trend equation for the development of the quantity of wheat production, it is clear from the equation presented in Table (2) that the linear form is the best fit for the nature of the data, and the general time trend formula shows that the amount of wheat production increases by a statistically significant amount about 169.4 thousand tons annually, representing about $2.1 \%$, and the results also show that, about $75 \%$ of the changes in the amount of wheat production are due to a group of factors whose impact is reflected by time factor.

\section{B- Development of the quantity of wheat imports:}

Table (1) shows the development of the quantity of wheat imports during the period (20002017), it found that the quantity of wheat imports reached a minimum in 2003 about 4.06 million tons, while it reached a maximum during 2014, when it was estimated by 11.21 million tons with an average about 8.07 million tons during the study period.

By studying the general time trend equation for the development of the quantity of wheat imports, it is clear from the equation presented in Table (2) that the linear form is the best fit for the nature of the data, and the general time trend formula shows that the amount of wheat imports increases with a statistically significant amount about 437.2 thousand tons annually, representing about $5.4 \%$, 
and the results show that, about $83 \%$ of the changes in the quantity of wheat imports are due to a group of variables whose effects are reflected by time factor.

Table 1: Development of the quantity of production, imports, exports, available for consumption, average per capita, self-sufficiency and lost quantity of wheat during the period (2000-2017).

(Quantity: thousand tons, average per capita: $\mathrm{kg}$ / year)

\begin{tabular}{cccccccc}
\hline Years & $\begin{array}{c}\text { Productio } \\
\text { n quantity }\end{array}$ & $\begin{array}{c}\text { Amount } \\
\text { of } \\
\text { imports }\end{array}$ & $\begin{array}{c}\text { Amount } \\
\text { of } \\
\text { exports }\end{array}$ & $\begin{array}{c}\text { Amount } \\
\text { available for } \\
\text { consumption }\end{array}$ & $\begin{array}{c}\text { Average } \\
\text { per } \\
\text { capita }\end{array}$ & $\begin{array}{c}\text { Self- } \\
\text { sufficiency } \\
\text { (\%) }\end{array}$ & $\begin{array}{c}\text { Lost } \\
\text { quantity(100 } \\
\text { 0 ton) }\end{array}$ \\
\hline $\mathbf{2 0 0 0}$ & 6564 & 4935 & 3 & 11188 & 136.32 & 58.7 & 445 \\
$\mathbf{2 0 0 1}$ & 6255 & 4449 & 23 & 11975 & 144.06 & 52.2 & 393 \\
$\mathbf{2 0 0 2}$ & 6625 & 5589 & 13 & 11751 & 137.62 & 56.4 & 465 \\
$\mathbf{2 0 0 3}$ & 6845 & 4064 & 30 & 11505 & 132.97 & 59.5 & 437 \\
$\mathbf{2 0 0 4}$ & 7178 & 4375 & 5 & 11963 & 135.48 & 60 & 470 \\
$\mathbf{2 0 0 5}$ & 8141 & 5785 & 35 & 13112 & 144.43 & 62.1 & 1167 \\
$\mathbf{2 0 0 6}$ & 8274 & 8024 & 32 & 16106 & 142.89 & 51.4 & 1390 \\
$\mathbf{2 0 0 7}$ & 7379 & 8251 & 25 & 16262 & 142.11 & 45.4 & 1377 \\
$\mathbf{2 0 0 8}$ & 7977 & 8335 & 28 & 16955 & 145.61 & 47 & 1521 \\
$\mathbf{2 0 0 9}$ & 8523 & 9130 & 111 & 17308 & 145.13 & 49.2 & 1605 \\
$\mathbf{2 0 1 0}$ & 7177 & 10607 & 89 & 17646 & 145.76 & 40.7 & 1872 \\
$\mathbf{2 0 1 1}$ & 8407 & 9836 & 181 & 18052 & 145.93 & 46.6 & 3376 \\
$\mathbf{2 0 1 2}$ & 8795 & 8269 & 148 & 17799 & 146.07 & 49.4 & 3131 \\
$\mathbf{2 0 1 3}$ & 9460 & 10331 & 191 & 19341 & 146.83 & 48.9 & 3275 \\
$\mathbf{2 0 1 4}$ & 8804 & 11207 & 249 & 19553 & 147.66 & 45 & 3560 \\
$\mathbf{2 0 1 5}$ & 9612 & 10721 & 337 & 19721 & 146.78 & 48.7 & 4142 \\
$\mathbf{2 0 1 6}$ & 9347 & 11179 & 342 & 20797 & 145.69 & 44.9 & 4367 \\
$\mathbf{2 0 1 7}$ & 8425 & 10201 & 419 & 17883 & 145.72 & 47.1 & 1971 \\
The & 7988.2 & 8071.6 & 125.6 & 16050.9 & 143.2 & 50.7 & 1942.4 \\
average & & & & & & & \\
\hline
\end{tabular}

Source: - FAO statistics, Internet.

- Ministry of Agriculture, food balance bulletins, various issues .

\section{C- Development of the quantity of wheat exports:}

Table (1) and Figure (1) show the evolution of the quantity of wheat exports during the period (2000-2017), it was found that the quantity of wheat exports reached a minimum in 2000 about 3 thousand tons, while it reached a maximum during 2017, when it was estimated by 419 thousand tons with an average about 125.6 thousand tons during the study period.

By studying the general time trend equation for the evolution of the quantity of wheat exports, it is clear from the equation presented in Table (2) that the linear form is the best fit for the nature of the data, and the general time trend equation shows that the quantity of wheat exports increases with a statistically significant amount about 22.7 thousand tons annually, representing about $18 \%$, and the results show that, about $83 \%$ of the changes in the quantity of wheat exports are due to a group of variables whose effects are reflected by time factor.

\section{D- Development of the amount available for wheat consumption:}

Table (1) and Figure (1) show the development of the amount available for consumption of wheat during the period (2000-2017), and it was found that, the amount of available for consumption of wheat reached a minimum in 2000 about 11.19 million tons, while it reached a maximum during 2016, it was estimated by 20.8 million tons, with an average about 16.05 million tons during the study period.

By studying the general time trend equation for the evolution of the amount of available for consumption of wheat, it is clear from the equation presented in Table (2) that the linear form is the best form appropriate for the nature of the data, and the general time trend formula shows that the amount of available for consumption of wheat increases by a statistically significant amount about 569.4 thousand tons annually, which represents about $3.5 \%$, as this percentage increases by $66.7 \%$ over production, which means a low percentage of wheat self-sufficiency. The results also showed that, about $88 \%$ of the changes in the amount available for consumption of wheat are due to a group of variables whose effects are reflected by time factor. 
Table 2: Estimations of the general time trend equations for the development of the quantity of production, imports, exports, available for consumption, average per capita and food gap of wheat during the period (2000-2017).

(Quantity: thousand tons, average per capita: $\mathrm{kg} /$ year)

\begin{tabular}{|c|c|c|c|c|}
\hline Variable & Estimated equation & $\mathbf{R}^{2}$ & $\mathbf{F}$ & $\begin{array}{l}\text { \%Annual } \\
\text { change }\end{array}$ \\
\hline $\begin{array}{l}\text { Production } \\
\text { quantity }\end{array}$ & $\begin{aligned} \hat{\mathrm{Y}}_{\mathrm{i}}= & 6379.2+169.4 \mathrm{X}_{\mathrm{i}} \\
& (23.9)^{* *}(6.9)^{* *}\end{aligned}$ & 0.75 & 47.2 & 2.1 \\
\hline $\begin{array}{l}\text { Amount of } \\
\text { imports }\end{array}$ & $\begin{aligned} \hat{\mathrm{Y}}_{\mathrm{i}}= & 3917.9+437.2 \mathrm{X}_{\mathrm{i}} \\
& (7.4)^{* *}(8.97)^{* *}\end{aligned}$ & 0.83 & 80.5 & 5.4 \\
\hline $\begin{array}{l}\text { Amount of } \\
\text { exports }\end{array}$ & $\begin{array}{c}\hat{Y}_{\mathrm{i}}=-89.7+22.7 \mathrm{X}_{\mathrm{i}} \\
(-3.2)^{* *}(8.8)^{* *}\end{array}$ & 0.83 & 76.8 & 18.0 \\
\hline $\begin{array}{l}\text { Available for } \\
\text { consumption }\end{array}$ & $\begin{aligned} \hat{\mathrm{Y}}_{\mathrm{i}}= & 10641.8+569.4 \mathrm{X}_{\mathrm{i}} \\
& (18.4)^{* *}(10.6)^{* *}\end{aligned}$ & 0.88 & 113.3 & 3.5 \\
\hline $\begin{array}{l}\text { Average per } \\
\text { capita } \\
\text { consumption }\end{array}$ & $\begin{aligned} \hat{Y}_{\mathrm{i}}= & 137.2+0.62 \mathrm{X}_{\mathrm{i}} \\
& (91.7)^{* *}(4.5)^{* *}\end{aligned}$ & 0.56 & 20.4 & 0.44 \\
\hline Self-sufficiency & $\begin{aligned} \hat{Y}_{\mathrm{i}}= & 58.5-0.82 \mathrm{X}_{\mathrm{i}} \\
& (87.4)^{* *}(4.1)^{* *}\end{aligned}$ & 0.50 & 16.2 & -1.6 \\
\hline Lost quantity & $\begin{aligned} \hat{Y}_{i}= & -196.8+225.2 X_{i} \\
& (-0.61) \quad(7.6)^{* *}\end{aligned}$ & 0.78 & 57.9 & 11.6 \\
\hline
\end{tabular}

Where:

$\hat{Y} i$ : estimated value of studied indicators for wheat crop.

$\mathrm{Xi}=\mathrm{a}$ variable that expresses the time of study years in observation (i) where $(\mathrm{i})=(1,2,3, \ldots, 18)$.

$(*)=$ Significant at 0.05 level, $(* *)=$ significant at 0.01 level.

Source: Results of the statistical analysis of the data presented in Table (1).

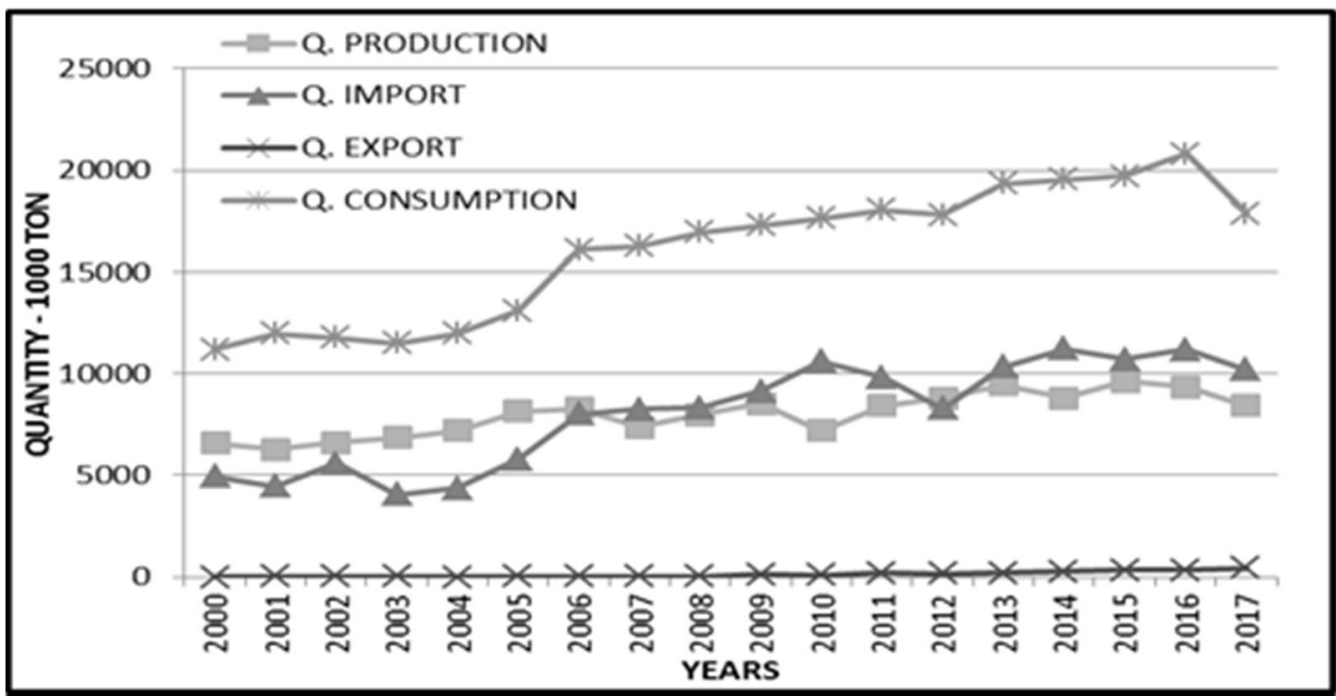

Fig. 1: Development of the quantity of production, imports, exports and available for consumption of wheat in Egypt during the period (2000-2017).

Source: From table (1).

\section{E - Development of the average per capita consumption of wheat:}

Table (1) and Figure (2) show the development of the average per capita consumption of wheat during the period (2000-2017), and it was found that the average per capita consumption of wheat reached a minimum in 2003 about $132.97 \mathrm{~kg}$ / year, while it reached its highest during 2014, it was estimated by $147.66 \mathrm{~kg}$ / year with an average about $143.2 \mathrm{~kg} /$ year during the study period.

By studying the general time trend equation for the development of the average per capita consumption of wheat, it is clear from the equation presented in Table (2) that the linear form is the best fit for the nature of the data, as the general time trend equation shows that the average per capita of 
wheat consumption increases by a statistically significant amount of $0.62 \mathrm{~kg}$ / year, representing about $0.44 \%$

As it is noticed from the figure that the average per capita decreased in recent years despite the increase in the amount of available consumption, due to the increase in the population by a greater rate than the increase in the amount available for consumption of wheat, as the results show that, about $56 \%$ of the changes in the average per capita consumption of wheat is due to a group of variables whose effects are reflected by time factor.

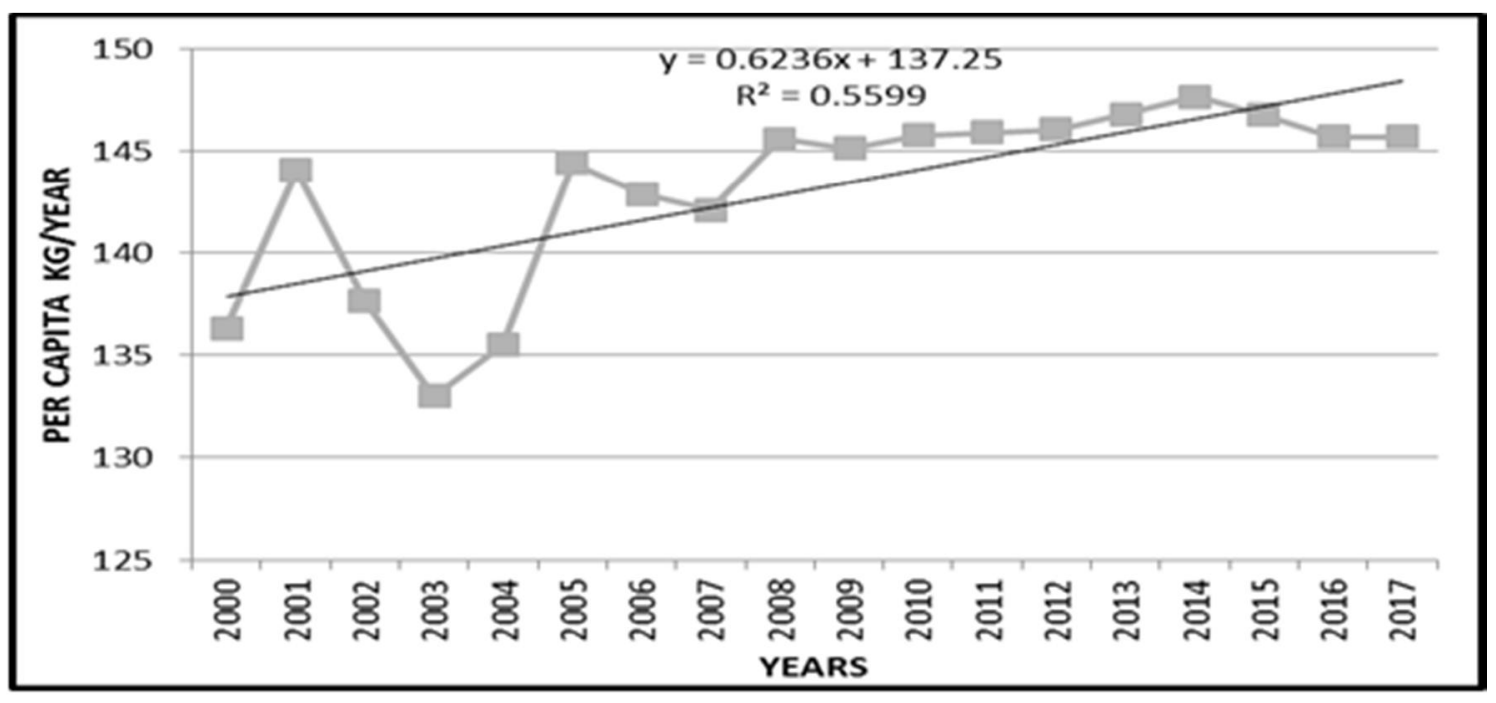

Fig. 2: Development of the average per capita consumption of wheat in Egypt during the period (20002017).

Source: From table (1).

\section{F- Development of self-sufficiency in wheat:}

Table (1) shows the development of wheat self-sufficiency during the period (2000-2017), and from it found that wheat self-sufficiency reached the lowest in 2010 about $40.7 \%$, while it reached its maximum during 2005 , when it was estimated by $62.1 \%$ with an average about $50.7 \%$ during the study period.

By studying the general time trend equation for the development of wheat self-sufficiency, it is clear from the equation presented in Table (2) that the linear form is the best fit for the nature of the data, and the general time trend equation shows that the self-sufficiency of wheat decreases by a statistically significant amount of $0.82 \%$ annually. The results also show that, about $50 \%$ of the changes in wheat self-sufficiency are due to a group of variables whose effects are reflected by time factor.

\section{G- Development of wheat lost quantity:}

Table (1) and Figure (4) show the development of wheat lost during the period (2000-2017), and from it found that the wheat lost reached below in the year 2001 about 393 thousand tons, while it reached its maximum during the year 2016 when it was estimated by 4.37 million tons with an average about 1.94 million tons during the study period.

By studying the general time trend equation for the evolution of wheat lost, it is clear from the equation presented in Table (2) that the linear form is the best fit for the nature of the data, and the general time trend equation shows that wheat lost is increasing by a statistically significant amount about 225.2 thousand tons annually, representing about $11.6 \%$ of the average, where it is noticed that the amount of wheat lost is large, representing approximately $20 \%$ to $40 \%$ of the supply of wheat. The results also show that, about $78 \%$ of the changes occurring in the wheat lost are due to a group of variables whose effects are reflected by time factor. 


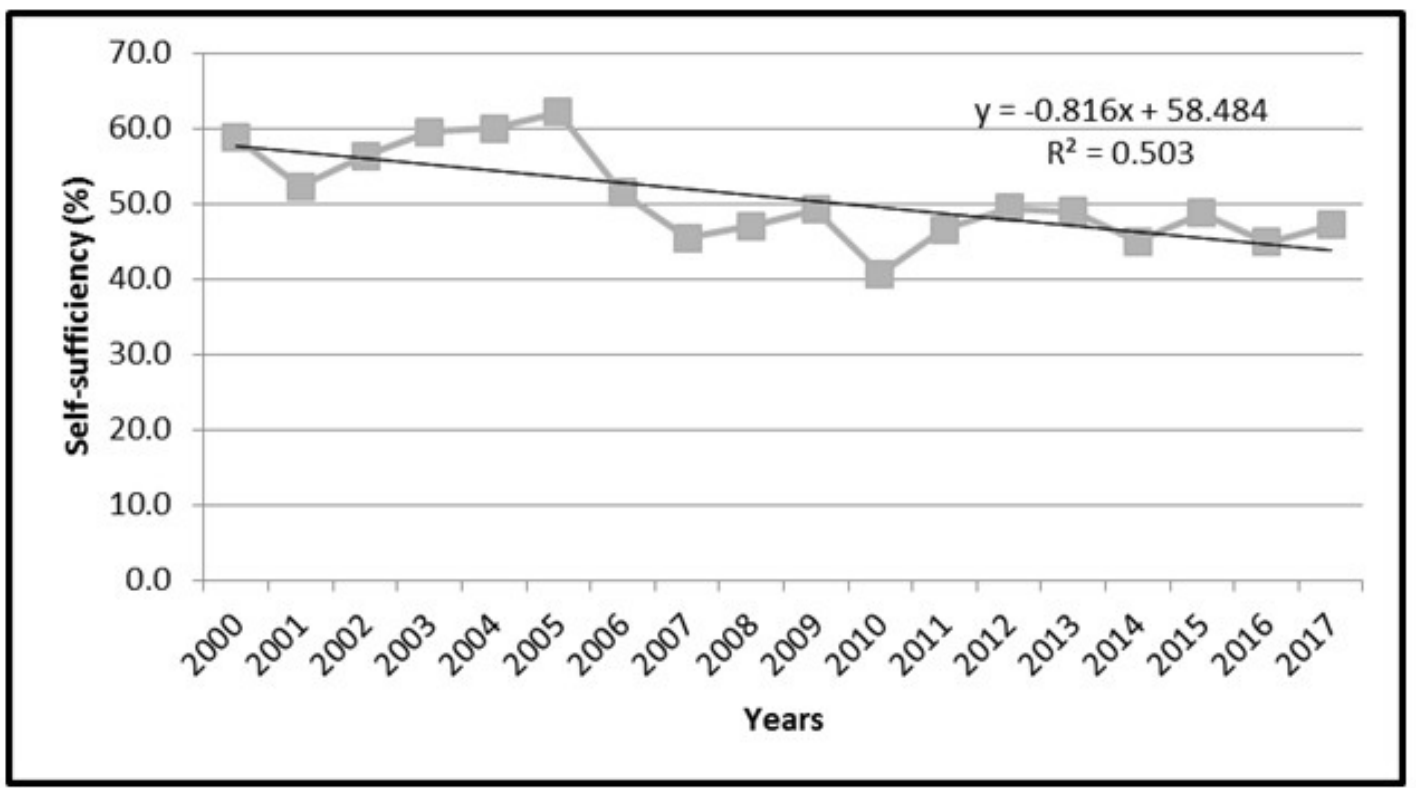

Fig. 3: Development of the self-sufficiency ratio of wheat in Egypt during the period (2000-2017) Source: From table (1).

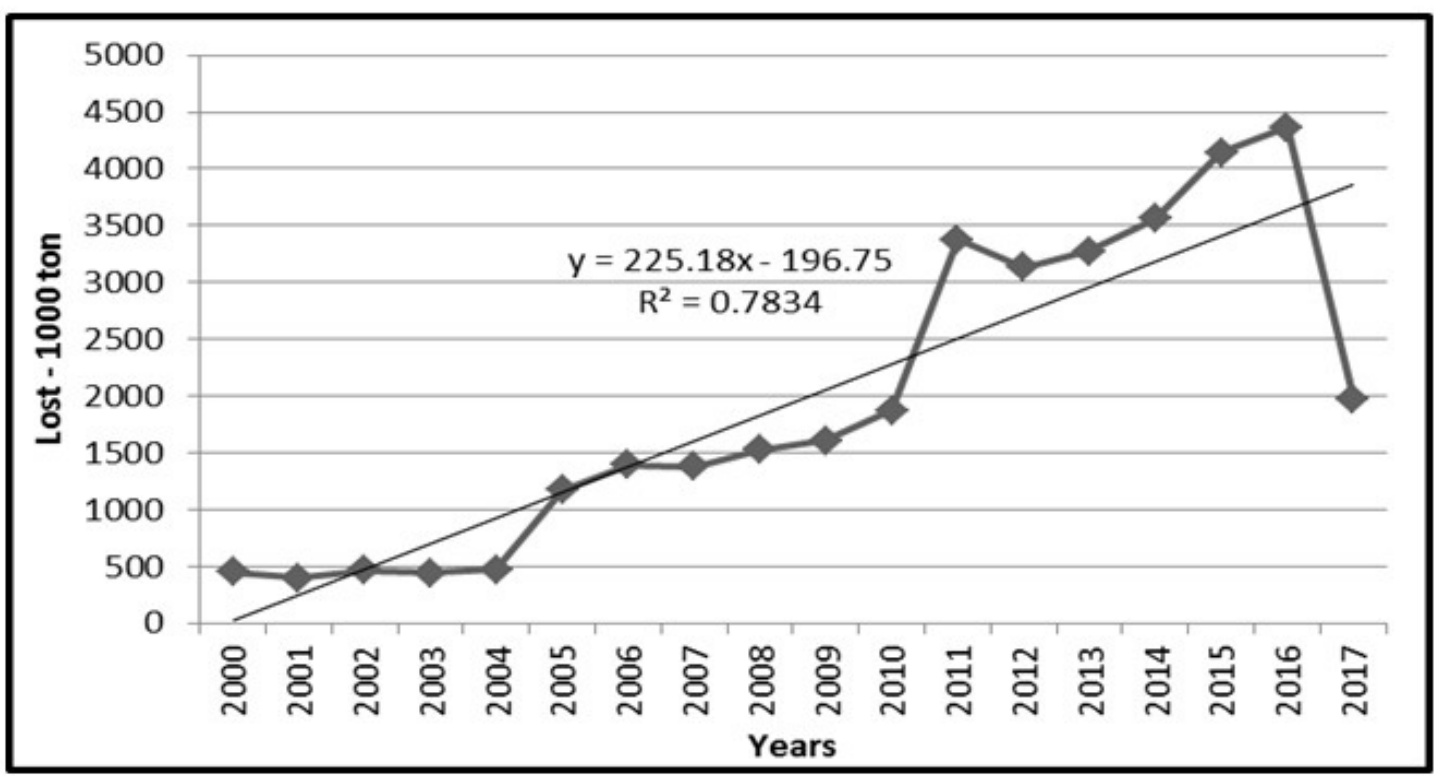

Fig. 4: Development of wheat lost in Egypt during the period (2000-2017)

Source: From table (1).

The relationship between the quantity of wheat lost and the quantity supplied of wheat (domestic production + imports):

By studying the regression relationship with the double logarithmic form and Figure (5) between each of the wheat supply quantity as an independent variable (X) and the amount of agricultural lost as a dependent variable (Y) it was found that, there is a direct relationship between the quantity of supply and the amount of lost, where the correlation coefficient value between them was 0.97 between the two variables as it was found that an increase in the amount of wheat supply by $1 \%$ leads to an increase in wheat waste by $1.8 \%$, and the coefficient of determination reached 0.94 , whereas $94 \%$ of the changes in the amount of lost due to the supply of wheat .

As it is noticed that the percentage of wheat lost is high, and therefore it is necessary to search for ways to reduce the lost.

$\operatorname{Ln} \hat{\mathbf{Y}}_{\mathbf{i}}=-24.2+1.8 \operatorname{Ln} \mathrm{X}_{\mathrm{i}}$ 


$$
\mathrm{R}=0.97 \quad \mathrm{R}^{2}=0.94 \quad \mathrm{~F}=238.7 * *
$$

\section{Whereas:}

$\hat{Y} i$ : the estimated value of the wheat lost. Xi: the amount of wheat supplied.

The value in parentheses indicates the calculated value of $(\mathrm{T}),(* *)$ of the statistical significance level at the level of $1 \%$. (R) correlation coefficient, $\left(\mathrm{R}^{2}\right)$ determinant coefficient. $(\mathrm{F})$ The significance of the model as a whole.

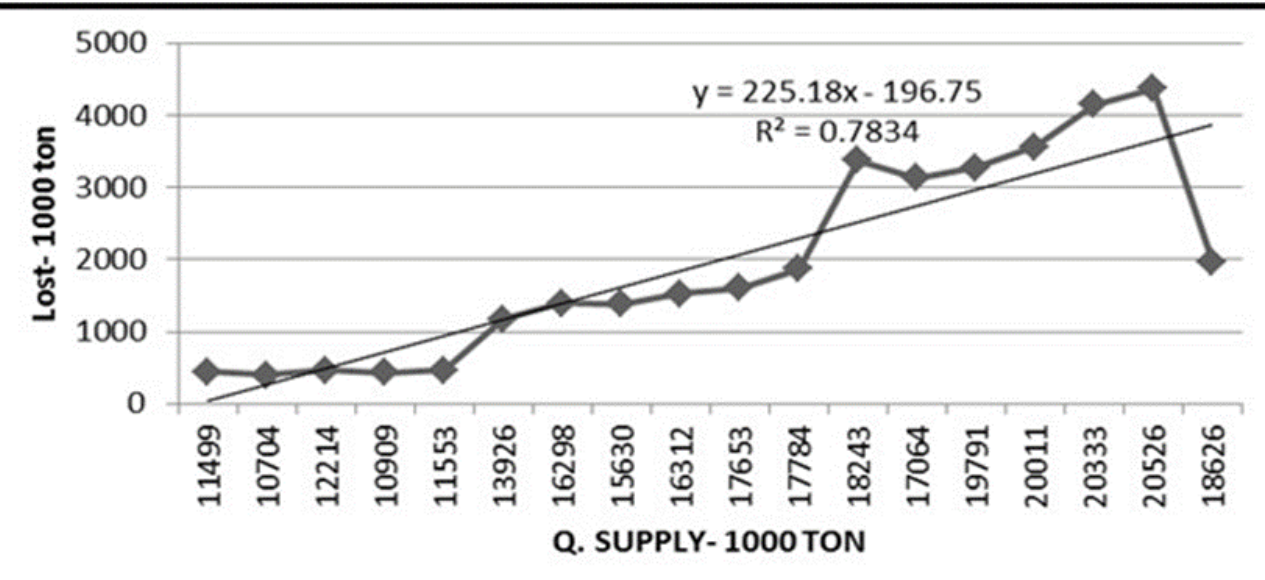

Figure (5): The relationship between the lost and the quantity of wheat in Egypt during the period (2000-2017).

Source: From table (1).

\section{Spatial planning for storing wheat in Egypt using the transportation model:}

The process of wheat storing is done by silos and shawn: silos are stores equipped with the latest methods and equipment to monitor and store stockpiles of cereals from any dangers related to weather, environmental and insect conditions. As for shawn, it is known as the empty place where cereals sacks can be stored until use.

The stored quantities of wheat are the sum of the quantities that are imported from the global market in addition to that, the local production that is optionally supplied by farmers. The state maintains what is produced and imported by reducing lost and maintaining the stock from damage until it is used in milling process for direct use as a loaf of bread.

\section{Classification of silos by type of use:}

1. Ports reception silos, which are called coastal silos, that specialize in receiving cereals coming to ports from abroad on ships. They are equipped with cereals pulling systems with high efficiency and reach up to 1400 tons / hour, which helps to speed the discharge of ships loaded with cereals to avoid delays and accumulation ships in ports.

2. Internal silos, called strategic storage silos, which are specialized in receiving cereals from the coastal port silos until they are distributed to all mills according to need and consumption.

3. Silos attached to the mills, which are specialized to receive the cereals coming from the internal silos and the silos of the ports for storage in the mills until they are grinded. They are silos of small capacities, but their number is greater than other silos.

\section{Classification of silos by building type:}

- Concrete silos (cement).

- Metal silos.

- Horizontal silos.

\section{Classification of silos according to their ownership:}

1. Public sector silos. 


\section{Silos of the private sector.}

\section{structure and estimating the transportation model for wheat in Egypt:}

First: structure and estimating the transportation model for wheat in Egypt for the year 2018:

This model addresses the governorates of Egypt producing wheat as well as imported ports (Safaga - Cairo - Port said - Suez - Damietta - Alexandria) as sources of wheat supply. On the other hand, the storage capacities of wheat, whether silos or shawn in those governorates, were identified as sources of demand for wheat (Destinations) to store wheat, the study relied on the use of 28 governorates in this regard, and the cost of one ton transporting was calculated, Considering that the cost of transportation cost per ton within the administrative area of the governorate is 100 pounds per ton, and this cost increases outside the governorate boundaries about 15 pounds per ton for each increase in the distance about $40 \mathrm{~km}$, and the distances between the governorates under study were estimated using Google Earth at the internet web.

The record data of the Supply Commodities Authority, the General Authority for Silos and Storage and the Ministry of Agriculture and Land Reclamation, were used in calculating the total storage capacity of wheat, which distributed at the level of the governorates of Egypt, which amounted about 1.4 million tons, the total quantities of wheat produced and distributed imports in the governorates of Egypt, which amounted about 11.65 Million tons, according to data from the Food and Agriculture Organization and the Export and Import Control Authority .

The research also made many attempts that amounted to about (35) attempts to reach the best transport pattern for wheat in Egypt to minimize transportation costs to the lowest possible, as the results of estimating the optimum solution for the wheat transportation model in Egypt showed in table (3) that the storage capacity of wheat ranges between a minimum of 165 tons in the Cairo governorate to a maximum about 392,000 tons.

In Alexandria Governorate, these storage capacities are distributed in the governorates of Kafr El Sheikh, Beheira, Menoufia, Damietta, Dakahlia, Alexandria, Ismailia, Qalyubia, Sharkia, Gharbia, Red Sea, Port Said, Suez, Cairo, Giza, Aswan, Fayoum, Qena, Sohag, New Valley, Beni Suef, Minya, Luxor, Marsa Matrouh, North Sinai, South Sinai, and Nubaria.

The results also show that, the most important storage capacities proposed to be established in those governorates, which is illustrated by the dummy variables distributed in the governorates under study (except Cairo and Qalyubia) as in table (3). The total transportation cost of distributed wheat on storage capacities in different governorates has reached 150.96 million pounds for the year 2018 .

Second: Expecting the results of estimating the optimum solution for the wheat transportation model:

\section{A- Targeting a storage capacity estimated 3 million tons in Egypt:}

Where statistics showed that the supplied quantity amounted about 15.5 million tons distributed in the governorates of Egypt at the same time that, there was not enough storage capacity to have capacity for this amount, the storage capacity in the governorates under study amounted to only 1.4 million tons.

The state moves towards setting the strategies needed to achieve a maximum storage capacity about 3 million tons in order to insurance the wheat food conditions in Egypt over a period about 2 months, which led to research towards making many attempts, which amounted about 35 attempts to reach the best transportation patterns through the minimum cost of wheat can be achieved, while specifying the size of the expected storage capacities and the locations of their distribution to the various governorates of Egypt.

Where the expected storage capacities to be established ranged about 42 tons as a minimum in North Sinai to a maximum of 5.2 million tons in Alexandria Governorate, with a total expected storage capacity about 8 million tons, where the expected storage capacities were concentrated in all governorates under study, ( Cairo and the Red Sea) as shown by the distribution of dummy variables in the governorates of the Republic in Table (4),

The total estimated cost of transporting 15.5 million tons and distributing it among the storage capacities proposed to be established is minimized to around 149.37 million pounds, where it less than the actual model about 1.59 million pounds. 
Middle East J. Agric. Res., 9(1): 34-45, 2020

Table 3: Results of estimating the optimum solution for the wheat transportation model in Egypt in the year of 2018

IRANSPORTATION MODEL OUTPUT SUMMARY

Title: Wheat1

Final Iteration No: 34

Objective Value $($ minimum cost) $=150975484.58$

\begin{tabular}{|c|c|c|c|c|c|}
\hline \multicolumn{2}{|c|}{ From } & To & \multirow{2}{*}{$\begin{array}{r}\text { Amt Shipped } \\
47920\end{array}$} & \multirow{2}{*}{$\begin{array}{r}\text { Obj Coeff } \\
10000\end{array}$} & \multirow{2}{*}{$\begin{array}{l}\text { Obj Contrib } \\
4792000.00\end{array}$} \\
\hline S1: & Kafr-El Sheikh & D1: Kafr-El Sheikh & & & \\
\hline S1: & Kafr-EI Sheikh & D8: Qalyoubia & 3520 & 113.13 & 398217.60 \\
\hline S1: & Kafr-El Sheikh & D29: DummyD & 538127 & 0.00 & 0.00 \\
\hline S2: & Behera & D2: Behera & 51440 & 100.00 & 5144000.00 \\
\hline S2: & Behera & D29: DummyD & 910245 & 0.00 & 0.00 \\
\hline S3: & Menoufia & D3: Menoufia & 63120 & 100.00 & 6312000.00 \\
\hline S3: & Menoufia & D14: Cairo & 76207 & 130.53 & 9947299.71 \\
\hline S3: & Menoufia & D29: DummyD & 244153 & 0.00 & 0.00 \\
\hline S4: & Damietta & D4: Damietta & 22000 & 100.00 & 2200000.00 \\
\hline S4: & Damietta & D29: DummyD & 292492 & 0.00 & 0.00 \\
\hline S5: & Dakahlia & D5: Dakahlia & 36080 & 100.00 & 3608000.00 \\
\hline S5: & Dakahlia & D29: DummyD & 661295 & 0.00 & 0.00 \\
\hline S6: & Alexandria & D6: Alexandria & 392000 & 100.00 & 39200000.00 \\
\hline S6: & Alexandria & D29: DummyD & 2537066 & 0.00 & 0.00 \\
\hline S7: & Ismailia & D7: Ismailia & 37360 & 100.00 & 3736000.00 \\
\hline s7: & Ismailia & D29: DummyD & 61300 & 0.00 & 0.00 \\
\hline S8: & Qalyoubia & D14: Cairo & 134759 & 115.53 & 15568707.27 \\
\hline S9: & Sharkia & D9: Sharkia & 31600 & 100.00 & 3160000.00 \\
\hline S9: & Sharkia & D29: DummyD & 874957 & 0.00 & 0.00 \\
\hline S10: & Gharbia & D10: Gharbia & 41840 & 100.00 & 4184000.00 \\
\hline S10: & Gharbia & D29: DummyD & 298267 & 0.00 & 0.00 \\
\hline S11: & Red sea & D11: Red Sea & 16000 & 100.00 & 1600000.00 \\
\hline $\mathrm{S} 12$ & Port Said & D12: Port Said & 0 & 100.00 & 0.00 \\
\hline S12: & Port Said & D29: DummyD & 46454 & 0.00 & 0.00 \\
\hline S13: & Suez & D13: Suez & 0 & 100.00 & 0.00 \\
\hline S13: & Suez & D29: DummyD & 25547 & 0.00 & 0.00 \\
\hline S14: & Cairo & D14: Cairo & 5034 & 10.00 & 50340.00 \\
\hline S15: & Giza & D15: Giza & 9280 & 100.00 & 928000.00 \\
\hline S15: & Giza & D29: DummyD & 90245 & 0.00 & 0.00 \\
\hline S16: & Assuit & D16: Assuit & 40560 & 100.00 & 4056000.00 \\
\hline S16: & Assuit & D29: DummyD & 538815 & 0.00 & 0.00 \\
\hline S17: & Aswan & D17: Aswan & 39560 & 100.00 & 3956000.00 \\
\hline S17: & Aswan & D29: DummyD & 101451 & 0.00 & 0.00 \\
\hline S18: & Fayoum & D18: Fayoum & 47040 & 100.00 & 4704000.00 \\
\hline S18: & Fayoum & D29: DummyD & 459559 & 0.00 & 0.00 \\
\hline S19: & Qena & D11: Red Sea & 84000 & 164.13 & 13786920.00 \\
\hline S19: & Qena & D19: Qena & 91120 & 100.00 & 9112000.00 \\
\hline S19: & Qena & D29: DummyD & 106973 & 0.00 & 0.00 \\
\hline S20: & Suhag & D20: Suhag & 51600 & 100.00 & 5160000.00 \\
\hline S20: & Suhag & D29: DummyD & 469931 & 0.00 & 0.00 \\
\hline S21: & New & D21: New Valley & 1600 & 100.00 & 160000.00 \\
\hline S21: & New & D29: DummyD & 437586 & 0.00 & 0.00 \\
\hline S22: & Beni Suef & D22: Beni Suef & 55280 & 100.00 & 5528000.00 \\
\hline $\mathrm{S} 22$ & Beni Suef & D29: DummyD & 292064 & 0.00 & 0.00 \\
\hline S23: & Menia & D23: Menia & 36840 & 10000 & 3684000,00 \\
\hline S23: & Menia & D29: DummyD & 594989 & 0.00 & 0.00 \\
\hline S24: & Luxor & D24: Luxor & 0 & 100.00 & 0.00 \\
\hline S24: & Luxor & D29: DummyD & 98027 & 0.00 & 0.00 \\
\hline S25: & Matruh & D25: Matruh & 0 & 100.00 & 0.00 \\
\hline S25: & Matruh & D29: DummyD & 44913 & 0.00 & 0.00 \\
\hline S26: & North Sinai & D26: North Sinai & 0 & 100.00 & 0.00 \\
\hline S26: & North Sinai & D29: DummyD & 42 & 0.00 & 0.00 \\
\hline S27: & South Sinai & D27: South Sinai & 0 & 100.00 & 0.00 \\
\hline S27: & South Sinai & D29: DummyD & 1712 & 0.00 & 0.00 \\
\hline$\$ 28:$ & Noubaria & D28: Noubaria & 0 & 100.00 & 0.00 \\
\hline S28: & Noubaria & D29: DummyD & 253659 & 0.00 & 0.00 \\
\hline
\end{tabular}

Source: Analysis results using Tora program. 
Table 4: Results of estimating the optimum solution for the wheat transportation model if targeting a storage capacity about 3 million tons.

\begin{tabular}{|c|c|c|c|c|c|c|}
\hline \multicolumn{7}{|c|}{$\begin{array}{l}\text { Title: Wheat } 3 \\
\text { Final iteration No: } 35 \\
\text { Objective Volue (minimum cost) }=149371875 \text {.50 }\end{array}$} \\
\hline \multicolumn{2}{|c|}{ From } & \multicolumn{2}{|l|}{ To } & \multirow{2}{*}{$\begin{array}{r}\text { Amt Shipped } \\
47920\end{array}$} & \multirow{2}{*}{$\frac{\text { Oby Coeff }}{100.00}$} & \multirow{2}{*}{$\begin{array}{l}\text { Obj Contrib } \\
479200000\end{array}$} \\
\hline S1: & Kafr-El Sheikh & D1: & Kafr-El Sheikh & & & \\
\hline Si: & Kofr-El Shoikh & $08:$ & Oalyoubia & 3520 & 113.13 & 398217.60 \\
\hline S1: & Kafr-El Sheikh & D29. & : Dummyo & 538127 & 0.00 & 0.00 \\
\hline s2: & Behera & D2 & Behere & 51440 & 10000 & 514400000 \\
\hline S2: & Behere & D29. & DummyD & 910245 & 0.00 & 0.00 \\
\hline \$3: & Monoufio & D3: & Monoufia & 63120 & 100.00 & 6312000.00 \\
\hline 53: & Monoufia & D14 & : Cairo & 71284 & 130.53 & 9304700.52 \\
\hline $53:$ & Monoufia & D20 & DummyD & 249076 & 0.00 & 0.00 \\
\hline S4: & Damiotta & D4: & Damietta & 22000 & 100.00 & 2200000.00 \\
\hline S4: & Damietta & D29. & DummyD & 537651 & 0.00 & 0.00 \\
\hline S5: & Dakahlia & DS: & Dakahliá & 36080 & 100.00 & 3608000.00 \\
\hline S5: & Dakahlia & D29. & Dummyo & 661295 & 0.00 & 0.00 \\
\hline S6: & Alexandria & D6: & Alexandria & 392000 & 100.00 & 39200000.00 \\
\hline s6: & Alexcondrio & 029 & Dummyo & 5247601 & 0.00 & 0.00 \\
\hline 57: & Ismailia & D7: & Ismailia & 37360 & 100.00 & 3736000.00 \\
\hline S7: & ismailia & D29. & DummyD & 61300 & 0.00 & 0.00 \\
\hline S8: & Qalyoubia & D14. & Cairo & 134759 & 115.53 & 15568707.27 \\
\hline S9: & $\begin{array}{l}\text { Sharkia } \\
\text { She }\end{array}$ & D9: & Sharkia & 31600 & 100.00 & 3160000.00 \\
\hline S9: & Sharkia & D29. & : DummyD & 874957 & 0.00 & 0.00 \\
\hline S10: & Gharbia & D10 & Gharbia & 41840 & 100.00 & 4184000.00 \\
\hline S10: & Gharbia & D29. & DummyD & 298267 & 0.00 & 0.00 \\
\hline S11: & Red soo & D11: & Rod Soo & 31753 & 100.00 & 3175300.00 \\
\hline S12: & Port Said & D 12 & Port Said & 0 & 10000 & 0.00 \\
\hline S12: & Port Said & D29. & DummyD & 59253 & 0.00 & 0.00 \\
\hline S13: & Suez & D13 & suez & 0 & 10000 & 000 \\
\hline S13: & suez & D29. & DummyD & 39377 & 0.00 & 0.00 \\
\hline S14: & Cairo & D14. & Cairo & 9957 & 10.00 & 99570.00 \\
\hline S15: & Giza & D15. & Giza & 9280 & 100.00 & 928000.00 \\
\hline Sis: & Giza & D20 & DummyD & 90245 & 0.00 & 0.00 \\
\hline S16: & Assuit & D16. & Assuit & 40560 & 100.00 & 4056000.00 \\
\hline S16: & Assuit & D29. & DummyD & 538815 & 0.00 & 0.00 \\
\hline S17: & Aswan & D17 & Aswon & 39560 & 100.00 & 3956000.00 \\
\hline S17: & Aswan & D29. & DummyD & 101451 & 0.00 & 0.00 \\
\hline S18: & Fayoum & D18: & Foyoum & 47040 & 100.00 & 4704000.00 \\
\hline S18: & Fayoum & D29 & DummyD & 459559 & 0.00 & 0.00 \\
\hline S19: & Dena & D11: & Red Sea & 68247 & 164.13 & 11201380.11 \\
\hline S19: & Dena & D19 & Dena & 91120 & 100.00 & 9112000.00 \\
\hline \$19: & Oeno & D29. & DummyD & 122726 & 0.00 & 0.00 \\
\hline 520: & suhog & D20 & Suhog & 51600 & 100.00 & 5160000.00 \\
\hline 520 : & Suhog & D29. & DummyD & 469031 & 0.00 & 0.00 \\
\hline S21: & Now & D21. & Now Volloy & 1600 & 100.00 & 160000.00 \\
\hline S21: & Now & 029 & DummyD & 437586 & 0.00 & 0.00 \\
\hline $522:$ & Beni Suef & 022 & Beni Suef & 55280 & 100.00 & 5528000.00 \\
\hline \$22: & Beni Suef & D29. & DummyD & 292064 & 0.00 & 0.00 \\
\hline \$23: & Menia & D23 & Menia & 36840 & 100.00 & 3684000.00 \\
\hline S23: & Menia & D29. & DummyD & 594989 & 0.00 & 0.00 \\
\hline $524:$ & Luxor & D24 & Luxor & 0 & 100.00 & 0.00 \\
\hline 524 & Luxor & D29. & DummyD & 98027 & 0.00 & 0.00 \\
\hline $525:$ & Matruh & D25. & Matruh & 0 & 100.00 & 0.00 \\
\hline S25: & Motruh & D29. & DummyD & 44913 & 0.00 & 0.00 \\
\hline \$26: & North Sinai & D26. & North Sinai & 0 & 100.00 & 0.00 \\
\hline \$26: & North Sinai & D29. & DummyD & 42 & 0.00 & 0.00 \\
\hline$\$ 27:$ & South Sinai & D27 & South Sinai & 0 & 100.00 & 0.00 \\
\hline 527: & South Sinai & 029 & DummyD & 1712 & 0.00 & 0.00 \\
\hline S28: & Noubaria & $\mathrm{D} 28$ & Noubaria & & 100.00 & 0.00 \\
\hline S28: & Noubaria & D29. & DummyD & 253659 & 0.00 & 0.00 \\
\hline
\end{tabular}

Source: Analysis results using Tora program.

\section{B- Targeting a storage capacity estimated by 6 million tons in Egypt:}

Where the statistics show that, the offered quantity amounted about 18.5 million tons distributed in the governorates of Egypt at the same time. There was not enough storage capacity to have capacity for this amount, as the storage capacity in the governorates under study amounted about 1.4 million tons only, which was called for the country's approach towards developing strategies which necessary to achieve storage capacity.

A maximum about 6 million tons in order to insurance the wheat food conditions in Egypt over a period about 5 month, which led to research towards conducting many attempts, which amounted about 35 attempts to reach the best models of transportation, which can achieve the minimum cost for transportation wheat with determining the scale of the expected storage capacities and the locations of their distribution to the governorates of Egypt

The storage capacities expected to be established ranged about 42 tons as a minimum in North Sinai about 7.96 million tons as a maximum in Alexandria Governorate, with a total expected storage capacity about 18.5 million tons, where the expected storage capacities were concentrated in all governorates under study, except the governorates ( Cairo and the Red Sea ) as shown by the distribution of dummy variables to the governorates of the Republic in Table (5)، As the total estimated cost of transporting 18.5 million tons and distributing it over the storage capacities proposed to be established is about 147.77 million pounds, less than the actual model about 3.19 million pounds . 
Table 5: Results of estimating the optimum solution for the wheat transportation model if targeting a storage capacity about 6 million tons.

TRANSPORTATION MODEL OUTPUT SUMMARY

Title: Wheat 6

Final Iteration No: 35

Objective Value (minimum cost) $=147768266.42$

\begin{tabular}{|c|c|c|c|c|c|}
\hline \multicolumn{2}{|c|}{ From } & To & \multirow{2}{*}{$\begin{array}{r}\text { Amt Shipped } \\
47920\end{array}$} & \multirow{2}{*}{$\begin{array}{r}\text { Obj Coeff } \\
100.00\end{array}$} & \multirow{2}{*}{$\begin{array}{l}\text { Obj Contrib } \\
4792000.00\end{array}$} \\
\hline S1: & Kafr-El Sheikh & D1: Kafr-El Sheikh & & & \\
\hline S1: & Kafr-El Sheikh & D8: Qalyoubia & 3520 & 113.13 & 398217.60 \\
\hline S1: & Kafr-El Sheikh & D29: DummyD & 538127 & 0.00 & 0.00 \\
\hline S2: & Behera & D2: Behera & 51440 & 100.00 & 5144000.00 \\
\hline $\mathrm{S} 2:$ & Behera & D29: DummyD & 910245 & 0.00 & 0.00 \\
\hline S3: & Menoufia & D3: Menoufia & 63120 & 100.00 & 6312000.00 \\
\hline S3: & Menoufia & D14: Cairo & 66361 & 130.53 & 8662101.33 \\
\hline S3: & Menoufia & D29: DummyD & 253999 & 0.00 & 0.00 \\
\hline S4: & Damietta & D4: Damietta & 22000 & 100.00 & 2200000.00 \\
\hline S4: & Damietta & D29: DummyD & 782810 & 0.00 & 0.00 \\
\hline S5: & Dakahlia & D5: Dakahlia & 36080 & 100.00 & 3608000.00 \\
\hline S5: & Dakahlia & D29: DummyD & 661295 & 0.00 & 0.00 \\
\hline S6: & Alexandria & D6: Alexandria & 392000 & 100.00 & 39200000.00 \\
\hline S6: & Alexandria & D29: DummyD & 7958136 & 0.00 & 0.00 \\
\hline S7: & Ismailia & D7: Ismailia & 37360 & 100.00 & 3736000.00 \\
\hline S7: & Ismailia & D29: DummyD & 61300 & 0.00 & 0.00 \\
\hline S8: & Qalyoubia & D14: Cairo & 134759 & 115.53 & 15568707.27 \\
\hline S9: & Sharkia & D9: Sharkia & 31600 & 100.00 & 3160000.00 \\
\hline S9: & Sharkia & D29: DummyD & 874957 & 0.00 & 0.00 \\
\hline \$10: & Gharbia & D10: Gharbia & 41840 & 100.00 & 4184000.00 \\
\hline S10: & Gharbia & D29: DummyD & 298267 & 0.00 & 0.00 \\
\hline S11: & Red sea & D11: Red Sea & 47506 & 100.00 & 4750600.00 \\
\hline S12: & Port Said & D12: Port Said & 0 & 100.00 & 0.00 \\
\hline S12: & Port Said & D29: DummyD & 72053 & 0.00 & 0.00 \\
\hline S13: & Suez & D13: Suez & 0 & 100.00 & 0.00 \\
\hline S13: & Suez & D29: DummyD & 47208 & 0.00 & 0.00 \\
\hline S14: & Cairo & D14: Cairo & 14880 & 10.00 & 148800.00 \\
\hline S15: & Giza & D15: Giza & 9280 & 100.00 & 928000.00 \\
\hline S15: & Giza & D29: DummyD & 90245 & 0.00 & 0.00 \\
\hline S16: & Assuit & D16: Assuit & 40560 & 100.00 & 4056000.00 \\
\hline S16: & Assuit & D29: DummyD & 538815 & 0.00 & 0.00 \\
\hline S17: & Aswan & D17: Aswan & 39560 & 100.00 & 3956000.00 \\
\hline S17: & Aswan & D29: DummyD & 101451 & 0.00 & 0.00 \\
\hline S18: & Fayoum & D18: Fayoum & 47040 & 100.00 & 4704000.00 \\
\hline S18: & Fayoum & D29: DummyD & 459559 & 0.00 & 0.00 \\
\hline S19: & Qena & D11: Red Sea & 52494 & 164.13 & 8615840.22 \\
\hline S19: & Qena & D19: Qena & 91120 & 100.00 & 9112000.00 \\
\hline S19: & Qena & D29: DummyD & 138479 & 0.00 & 0.00 \\
\hline S20: & Suhag & D20: Suhag & 51600 & 100.00 & 5160000.00 \\
\hline S20: & Suhag & D29: DummyD & 469931 & 0.00 & 0.00 \\
\hline S21: & New & D21: New Valley & 1600 & 100.00 & 160000.00 \\
\hline S21: & New & D29: DummyD & 437586 & 0.00 & 0.00 \\
\hline S22: & Beni Suef & D22: Beni Suef & 55280 & 100.00 & 5528000.00 \\
\hline S22: & Beni Suef & D29: DummyD & 292064 & 0.00 & 0.00 \\
\hline S23: & Menia & D23: Menia & 36840 & 100.00 & 3684000.00 \\
\hline S23: & Menia & D29: DummyD & 594989 & 0.00 & 0.00 \\
\hline S24: & Luxor & D24: Luxor & 0 & 100.00 & 0.00 \\
\hline S24: & Luxor & D29: DummyD & 98027 & 0.00 & 0.00 \\
\hline S25: & Matruh & D25: Matruh & 0 & 100.00 & 0.00 \\
\hline S25: & Matruh & D29: DummyD & 44913 & 0.00 & 0.00 \\
\hline S26: & North Sinai & D26: North Sinai & 0 & 100.00 & 0.00 \\
\hline S26: & North Sinai & D29: DummyD & 42 & 0.00 & 0.00 \\
\hline S27: & South Sinai & D27: South Sinai & 0 & 100.00 & 0.00 \\
\hline \$27: & South Sinai & D29: DummyD & 1712 & 0.00 & 0.00 \\
\hline S28: & Noubaria & D28: Noubaria & 0 & 100.00 & 0.00 \\
\hline S28: & Noubaria & D29: DummyD & 253659 & 0.00 & 0.00 \\
\hline
\end{tabular}

Source: Analysis results using Tora program. 


\section{Recommendations:}

- Multiply the state efforts to develop wheat storage capacities.

- Search for innovative ways to reduce losses resulting from transportation, storage and human use.

- Activating the extension role to carry out campaigns to aware farmers about the new varieties and agricultural methods that increase fedden productivity.

- Expanding the construction of silos to accommodate the produced and imported quantities.

- Build silos under the ground in strategic locations to avoid any disturbances.

- Development of soil shuns to reduce wheat lost and spoilage.

- Give public and government sectors the priority of supply.

- Establishing subsidiaries of the Egyptian Holding Company for Silos and Storage, to manage and operate silos, one for Lower Egypt Silos and one for Upper Egypt Silos.

- Establishing a major logistic company working in the field of trading and storing food, agricultural products and cereals.

\section{References}

Abdullah M. Abdelmaqsoud, Ashraf Y. Shebl, 2018. An economic study for spatial planning of Egyptian agricultural foreign trade in the most important African markets, Suez University.

Abeer Bashir Mohamed and Ghada Abdel Fattah Mostafa, 2013., An Analytical Study of the Production and Import Status of the Wheat Crop in Egypt, The Egyptian Journal of Agricultural Economics, The Egyptian Society for Agricultural Economics, Twenty-third Volume, Fourth Issue,

Ahmad Muhammad Faraj Qasim, 2013. Productive and Economic Efficiency of the Most Important Varieties of Wheat Cultivated in Beheira Governorate, Egyptian Journal of Agricultural Economics, Egyptian Society for Agricultural Economics, Volume Twenty, Number two.

Ahmed Mahmoud Abdel-Aziz Mohamed, 2016. An economic study on the effect of price changes on the rice crop in Egypt, Egyptian Journal of Agricultural Economics, volume twenty-sixth, number two.

Ahmed Mahmoud Imam Radwan, Kamal Salama Arafat, 2013. The current clarity of the food gap in wheat in Egypt and the possibilities of reducing it, The Egyptian Journal of Agricultural Economics Egyptian Society for Agricultural Economics, Volume Twenty-third, Number two.

Damodar N. Gujarati, Basic Econometrics, $4^{\text {th }}$ ed, McGraw-Hill Companies, 2004.

Fathia Farid Abdullah Al-Sayed, 2014. A study on estimating the productivity of rice and sugar beet crops in the sample in light of different types of irrigation water and the location of the field in Kafr El-Sheikh Governorate, Egyptian Journal of Agricultural Economics, Volume Twenty-fourth, Fourth Issue.

Hani Saeed Abdel-Rahman Al-Shatleh and Hussam Al-Din Muhammad Muhammad Siddiq, 2013. Solving the Wheat Problem in Egypt ... Possible Methods, the Egyptian Journal of Agricultural Economics, Egyptian Society for Agricultural Economics, Volume Twenty-Third, Number two, Jeffrey, M., 2003. Wooldridge, Introductory Econometrics- A Modern Approach, $2^{\text {nd }}$ ed. William H. Greene, 2003. Econometric Analysis, $5^{\text {th }}$ ed, New York University.

Samah Mohamed Ibrahim Shaheen, 2018. The Economics of cereals Storage in Egypt, department of Agricultural Economics, faculty of agriculture, Ain shams university, 2018 